\title{
Anthelmintic pyrvinium pamoate blocks Wnt/ $\beta$-catenin and induces apoptosis in multiple myeloma cells
}

\author{
FANG XU ${ }^{1}$, YINGJIE ZHU ${ }^{1}$, YUHONG LU ${ }^{2}$, ZHI YU ${ }^{2}$, JUN ZHONG $^{2}$, YANGQIU LI $^{2}$ and JINGXUAN PAN ${ }^{1}$ \\ ${ }^{1}$ Jinan University Institute of Tumor Pharmacology, College of Pharmacy; ${ }^{2}$ Department of Hematology, \\ First Affiliated Hospital, Jinan University, Guangzhou, Guangdong 510632, P.R. China
}

Received December 28, 2016; Accepted December 21, 2017

DOI: $10.3892 / \mathrm{ol} .2018 .8006$

\begin{abstract}
Multiple myeloma (MM) is a malignancy of the bone marrow. The median survival time of patients with $\mathrm{MM}$ is only 5 years, with patients frequently experiencing relapse. Currently, there is no effective therapy for recurrent MM. The results of the present study indicated that pyrvinium pamoate (PP), a US Food and Drug Administration-approved oral anthelmintic drug, exhibited potent antitumor activity in $\mathrm{MM}$ cells in vitro. It is demonstrated that PP inhibited MM cell proliferation and mediated apoptosis. Notably, PP markedly promoted the degradation of $\beta$-catenin and abrogated its phosphorylation. PP triggered apoptosis in MM cells by inducing the release of cytochrome $\mathrm{c}$ and downregulating the expression of myeloid leukemia cell differentiation protein. In addition, PP effectively induced cell death in primary MM cells. In conclusion, PP may be a promising agent for the clinical treatment of MM.
\end{abstract}

\section{Introduction}

Multiple myeloma (MM) is characterized by the clonal expansion of malignant plasma cells that may result in organ damage, including lytic bone lesions, anemia, renal failure or hypercalcemia $(1,2)$. This malignant disease accounts for $13 \%$ of cases of hematological cancer, and the median survival time of patients is only 5 years (3). Plasma cells and monoclonal immunoglobulins are responsible for the manifestations of the disease. The progression of MM involves primary cytogenetic abnormalities (cyclin D, fibroblast growth factor receptor 3, histone-lysine N-methyltransferase, or musculoaponeurotic fibrosarcoma) in myeloma-initiating cells. The oncogenic growth of MM cells is hypothesized to be supported by intracellular oncogenic events and tumor

Correspondence to: Professor Jingxuan Pan, Jinan University Institute of Tumor Pharmacology, College of Pharmacy, Jinan University, 601 West Huangpu Boulevard, Guangzhou, Guangdong 510632, P.R. China

E-mail: jingx_pan@163.com

Key words: multiple myeloma, apoptosis, synergism, $\beta$-catenin microenvironment components, such as bone marrow stromal cells (4-6).

Although the introduction of thalidomide, lenalidomide and bortezomib into the clinic has markedly improved the response rates and survival in patients with MM (7), the disease remains largely incurable owing to relapse and drug resistance $(8,9)$. Identifying novel agents to overcome the adverse effects of current therapies remains an important task in the clinic.

The abnormal activation of the Wnt/ $\beta$-catenin pathway in multiple types of cancer, including lymphomas and MM, makes it an attractive therapeutic target $(10,11)$. Notably, the $\mathrm{Wnt} / \beta$-catenin pathway is constitutively active in MM, which is hypothesized to be associated with promoting tumor cell proliferation, progression and resistance to chemotherapy (11). Blocking the Wnt $/ \beta$-catenin signaling pathway suppresses the progression of $\mathrm{MM}$, which indicates that a potential therapeutic approach would be to intervene in the $\mathrm{Wnt} / \beta$-catenin pathway $(12,13)$.

Pyrvinium pamoate [6-(dimethylamino)-2-[2(2,5-dimethyl-1-phenylpyrrol-3-yl) ethenyl]-1-methylquinolinium; PP], commercially known as Povan or Vanquin, is a US Food and Drug Administration (FDA)-approved oral anthelmintic drug (14). It is approved for the treatment of enterobiasis, with a safe human dosage of $5-35 \mathrm{mg} / \mathrm{kg} /$ day. PP has been identified to be markedly cytotoxic to a number of cancer cell lines (15). PP is able to inhibit Wnt/ $\beta$-catenin signaling through the activation of casein kinase $1 \alpha$ and may regulate the stability of $\beta$-catenin and axin in the cytoplasm and Pygopus and T-cell factor/lymphoid enhancer-binding factor 1 in the nucleus (16). PP inhibits mitochondrial NADH-fumarate reductase activity and disrupts mitochondrial energy metabolism within the tumor microenvironment (17). Furthermore, $\mathrm{PP}$ is a non-competitive androgen receptor (AR) inhibitor and inhibits endogenous AR activity in two prostate cancer cell lines, LANCaP and LAPC4 (18). PP may also reduce the expression of several androgen-responsive genes in LANCaP cells (18).

In the present study, it was hypothesized that PP induced apoptosis in MM by blocking Wnt/ $\beta$-catenin signaling. The results of the present study revealed that PP markedly inhibited the growth of MM cells, facilitated apoptosis by damaging mitochondria and triggering the intrinsic apoptosis pathway, and destabilized $\beta$-catenin in MM. These 
results provide support for the clinical usage of PP in MM treatment.

\section{Materials and methods}

Cell culture and reagents. The MM cell lines MM.1S, U266 and RPMI-8226 were purchased from the American Type Culture Collection (ATCC; Manassas, VA, USA); LP1 and OCI-MY5 cell lines were kindly provided by Dr. Xinliang Mao (Soochow University, Suzhou, China) (19). Cells were cultured in Iscove's Modified Dulbecco's Medium (IMDM; Thermo Fisher Scientific, Inc., Waltham, MA, USA) supplemented with $10 \%$ fetal bovine serum (FBS; Biological Industries, Kibbutz Beit Haemek, Israel). Cells were incubated at $37^{\circ} \mathrm{C}$ in humidified air with $5 \% \mathrm{CO}_{2}$ at atmospheric pressure. PP (CAS: 3546-41-6) was purchased from Sigma-Aldrich (Merck KGaA, Darmstadt, Germany); and dissolved in dimethyl sulfoxide (DMSO), giving a $20 \mathrm{mM}$ stock solution that was frozen in aliquots and stored at $-20^{\circ} \mathrm{C}$. Bortezomib (cat. no. 179324-69-7) was obtained from Sigma-Aldrich (Merck KGaA). Antibodies against poly (ADP-ribose) polymerase (PARP; 1:8,000; cat. no. 556362), B-cell lymphoma 2 (Bcl-2; 1:1,000; cat. no. 551097), X-linked inhibitor of apoptosis protein (XIAP; 1:1,000; cat. no. 610716), active caspase-3 (1:1,000; cat. no. 559565), caspase-3 (1:1,000; cat. no. 610322), -8 (1:1,000; cat. no. 556466) and -9 (1:1,000; cat. no. 551247) were obtained from BD Pharmingen (BD Biosciences, San Jose, CA, USA); anti-Bcl-2-like protein (Bim, 1:1,000; cat. no. sc-374358), B-cell lymphoma-extra-large (Bcl-XL; 1:500; cat. no. sc-8392) and induced myeloid leukemia cell differentiation protein (Mcl-1; 1:500; cat. no. sc-12756) were obtained from Santa Cruz Biotechnology, Inc. (Dallas, TX, USA); anti-survivin (1:1,000; cat. no. SAB3500269) and anti- $\beta$-actin $(1: 8,000$; cat. no. A1978) antibodies were obtained from Sigma-Aldrich (Merck, KGaA). Antibodies against $\beta$-catenin $(1: 1,000$; cat. no. 9562), phospho- $\beta$-catenin (Ser33/37/Thr41, 1:1,000; cat. no. 9561), phospho-GSK3 $\beta$ (S9, 1:1,000; cat. no. 9323), c-Myc (1:1,000; cat. no. 9402), Cyclin D1 (1:1,000; cat. no. 2922), Cytochrome $c$ (Cyto $c$; 1:1,000; cat. no. 4272) and tubulin (1:1,000; cat. no. 2148) were from Cell Signaling Technology, Inc. (Danvers, MA, USA). Anti-cyto $c$ oxidase subunit II (COX II; 1:1,000; cat. no. PA5-75199) was obtained from Molecular Probes (Thermo Fisher Scientific, Inc.). Antibody phospho-GSK3 $\beta$ (Y216, 1:1,000; cat. no. ab75745) was purchased from Abcam (Cambridge, UK), IRDye ${ }^{\circledR} 800 \mathrm{CW}$ goat anti-mouse IgG (H+L) $(1: 10,000$; cat. no. 925-32210) and IRDye ${ }^{\circledR} 800 \mathrm{CW}$ goat anti-rabbit IgG $(\mathrm{H}+\mathrm{L})(1: 10,000$; cat. no. 925-32211) secondary antibodies were from LI-COR Biosciences (Lincoln, NE, USA).

Primary cells. Peripheral blood samples or bone marrow aspirates were obtained from patients with MM $(n=5)$ in the First Affiliated Hospital of Jinan University (Guangzhou, China). Patient clinicopathological information is in Table I. Mononuclear cells were isolated by Ficoll separation using Histopaque-1077 (density 1.077 g/ml; Sigma-Aldrich; Merck $\mathrm{KGaA}$ ). Briefly, $3 \mathrm{ml}$ Histopaque-1077 was added to a $15 \mathrm{ml}$ centrifuge tube until room temperature was attained, then $3 \mathrm{ml}$ of whole blood was carefully layered onto the Histopaque-1077. Following centrifugation at $400 \mathrm{x} \mathrm{g}$ for $30 \mathrm{~min}$ at room temperature, the opaque interface was carefully transferred into a clean centrifuge tube. Contaminating red cells were lysed in $0.8 \%$ ammonium chloride solution for $10 \mathrm{~min}$. Following three washes with PBS, cells were suspended in IMDM supplemented with $10 \% \mathrm{FBS}$ and incubated at $37^{\circ} \mathrm{C}$ in water vapor-saturated air with $5 \% \mathrm{CO}_{2}$ at one atmospheric pressure. The present study was approved by the Ethics Committee of Jinan University; each patient provided written informed consent for inclusion in the present study.

Cell viability assay. Cell viability was evaluated using an MTS assay (CellTiter 96 Aqueous One Solution reagent; Promega Corporation, Madison, WI, USA) as described previously $(20,21)$. Briefly, $2 \times 10^{4}$ cells in $100 \mu 1$ were exposed to various concentrations of PP $(100,50,25,12.5,6.25,3.125$, $1.5625,0.78,0.39$ and $0.19 \mathrm{nM}$ ) for $72 \mathrm{~h}$. Control cells were treated with DMSO instead at a final concentration $<0.1 \%$ as the highest concentration of PP. A total of $20 \mu \mathrm{l}$ of MTS solution per well was added $4 \mathrm{~h}$ prior to culture termination. Absorbance was read at $490 \mathrm{~nm}$ using a 96-well plate reader.

The combination between PP $(80,40,20,10$ and $5 \mathrm{nM})$ and bortezomib (4, 2, 1, 0.5, 0.25 and $0.125 \mathrm{nM})$ in MM cells were determined by MTS assay. The combinational effects were evaluated by use of the CalcuSyn software (version 2.0; BIOSOFT, Cambridge, UK). Combination index (CI) was the ratio of the combination dose to the sum of the single-agent doses at an isoeffective level. CI $<1$ indicates synergy; CI $>1$, antagonism; and $\mathrm{CI}=1$, additive.

Western blot analysis. Whole lysates were prepared with radioimmunoprecipitation assay (RIPA) buffer [1x PBS, $1 \%$ NP-40, $0.5 \%$ sodium deoxycholate, $0.1 \%$ SDS, added $10 \mathrm{mM} \beta$-glycerophosphate, $1 \mathrm{mM}$ sodium orthovanadate, $10 \mathrm{mM} \mathrm{NaF}, 1 \mathrm{mM}$ phenylmethylsulfonyl fluoride (PMSF)] and 1x Roche Complete Mini Protease Inhibitor Cocktail (Roche Diagnostics, Indianapolis, IN, USA) prior to usage. The cytosolic extract was prepared with digitonin extraction buffer [1 mM piperazine-N, N'bis ( $\mathrm{pH}=6.8), 300 \mathrm{mM}$ sucrose, $0.015 \%$ digitonin, $3 \mathrm{mM} \mathrm{MgCl} 2,5 \mathrm{mM}$ EDTA, $100 \mathrm{mM} \mathrm{NaCl}$ and $1 \mathrm{mM}$ PMSF] for measuring the levels of cyto $c$ in the cytosol. Immunoblotting of whole-cell lysates prepared in RIPA buffer was performed as previously reported (22-24). The protein concentration was determined using a Bicinchoninic Acid kit (cat. no. p0010, Beyotime Institute of Biotechnology, Haimen, China). Protein samples ( $25 \mu \mathrm{g}$ per sample) were separated on $10 \%$ SDS-PAGE gel and transferred to nitrocellulose (NC) membranes, which were then blocked with milk $(0.5 \% \mathrm{NaN} 3)$ for $1 \mathrm{~h}$ at room temperature, each lane was excised according to the mass of protein [phosphor- $\beta$-catenin(S33/37/T41) and $\beta$-catenin: $90 \mathrm{kDa}$; phospho-GSK3 $\beta$ (S9), phospho-GSK3 $\beta$ (Y216) and GSK3 $\beta$ : 51, $46 \mathrm{kDa}$; C-myc: $62 \mathrm{kDa}$; Cyclin D1: $36 \mathrm{kDa}$; $\beta$-actin: $43 \mathrm{kDa}$; PARP: $116,85 \mathrm{kDa}$; active-caspase-3: $17 \mathrm{kDa}$, caspase-3: $35 \mathrm{kDa}$; caspase-8: $57 \mathrm{kDa}$; caspase-9: 47 kDa; Mcl-1: 42 kDa; XIAP: 64, 57 kDa; Bcl-2: 26 kDa; Bcl-XL: $23 \mathrm{kDa}$; Bim: 23, 16 and $13 \mathrm{kDa}$; COXII: $74 \mathrm{kDa}$; Cyto $c$ : $14 \mathrm{kDa}$; Tubulin: $55 \mathrm{kDa}$ and then incubated with the aforementioned primary antibodies overnight at $4^{\circ} \mathrm{C}$. Following incubation with the aforementioned secondary antibodies for $1 \mathrm{~h}$ at room temperature, the $\mathrm{NC}$ membranes were scanned using the Odyssey infrared imaging system (LI-COR) with no further staining or visualization reagent. 
Table I. Characteristics of patients with multiple myeloma.

\begin{tabular}{|c|c|c|c|c|c|c|c|}
\hline $\begin{array}{l}\text { Patient } \\
\text { no. }\end{array}$ & $\begin{array}{l}\text { Gender/age, } \\
\text { years }\end{array}$ & Sample & $\begin{array}{l}\text { M-component } \\
\text { type }\end{array}$ & $\begin{array}{l}\text { Stage } \\
(\text { ISS })^{\mathrm{a}}\end{array}$ & $\begin{array}{l}\text { Plasma } \\
\text { cells, \% }\end{array}$ & Cytogenetics & Last treatment \\
\hline 1 & $\mathrm{~F} / 67$ & PB & ND & ND & 87 & ND & $\begin{array}{l}\text { Bortezomib, epirubicin } \\
\text { and dexamethasone }\end{array}$ \\
\hline 2 & $\mathrm{M} / 41$ & PB & $\operatorname{IgG}-\lambda$ & IIIB & 49.5 & $\begin{array}{l}\text { CKs1B/CDKN2C (P18), } \\
\text { RB1 (13q14), and } \\
\text { IgH amplification }\end{array}$ & $\begin{array}{l}\text { Dexamethasone, } \\
\text { lenalidomide and } \\
\text { prednisone }\end{array}$ \\
\hline 3 & $\mathrm{~F} / 49$ & $\mathrm{BM}$ & $\operatorname{IgD}-\lambda$ & III & 79.5 & RB1(13q14) deletion & $\begin{array}{l}\text { Bortezomib, dexamethasone, } \\
\text { thalidomide and mephalan }\end{array}$ \\
\hline 4 & $\mathrm{M} / 53$ & PB & $\operatorname{Ig} \mathrm{A}-\kappa$ & IIA & 84 & $\begin{array}{l}\text { RB1, D13s319, 1q21, } \\
\text { and IgH amplification }\end{array}$ & Lenalidomide \\
\hline 5 & $\mathrm{~F} / 63$ & PB & $\operatorname{IgG}-\lambda$ & ND & 33.5 & ND & $\begin{array}{l}\text { Bortezomib, dexamethasone } \\
\text { and doxorubicin }\end{array}$ \\
\hline
\end{tabular}

${ }^{\mathrm{a}}(33)$. PB, peripheral blood; BM, bone marrow; ND, not detected; Ig, immunoglobulin; RB1, retinoblastoma protein; CDKN2C, cyclin dependent kinase inhibitor 2C; ISS, international staging system.

Trypan blue exclusion assay. Cells were stained with $0.4 \%$ trypan blue (Sigma-Aldrich; Merck KGaA) dissolved in water immediately $\left(1-10 \times 10^{5} / \mathrm{ml}\right.$, at room temperature), then the cell numbers were counted under an inverted phase-contrast microscope.

Colony-formation assay. MM cells were treated with different concentrations of PP $(120,60$ or $30 \mathrm{nM}$ of LP1, and 200, 100 or $50 \mathrm{nM}$ of RPMI-8226, respectively) or diluent (DMSO, control) for $48 \mathrm{~h}$ at $37^{\circ} \mathrm{C}$ in water vapor-saturated air with $5 \% \mathrm{CO}_{2}$, washed with PBS, and then seeded in IMDM containing $0.3 \%$ agar and $20 \%$ FBS in the absence of drug treatment $(22,25)$. Colonies (containing $\geq 50$ cells) were counted under an inverted optical microscope (Olympus, Japan) following two weeks of incubation at $37^{\circ} \mathrm{C}$.

Transfection of plasmids. Human pCMV6-flag- $\beta$-catenin and empty vector equivalents was obtained from Addgene, Inc. (Cambridge, MA, USA). Plasmids or empty vector $(2 \mu \mathrm{g})$ were delivered into RPMI-8226 in $10 \mathrm{ml}$ medium using polyethylenimine reagent $(6 \mu \mathrm{g})$. Briefly, plasmids or empty vector $(2 \mu \mathrm{g})$ were mixed with polyethylenimine (PEI, Polysciences, Warrington, PA) in $1 \mathrm{ml}$ opti-MEM and then added to target cells in $10 \mathrm{~cm}$ dish (containing $9 \mathrm{ml}$ RPMI-1640 medium). The medium was changed for fresh IMDM culture after $8 \mathrm{~h}$, and then cells were exposed to PP (100 or $200 \mathrm{nM}$, respectively) for $48 \mathrm{~h}$ at $37^{\circ} \mathrm{C}$. Trypan blue exclusion assays and Western blotting analysis were then performed as aforementioned.

Lentiviral transduction in MM cells. Lentiviruses were produced by transient transfection in 293T cells purchased from the ATCC using control scrambled short hairpin RNA (shRNA) and specific shRNA against $\beta$-catenin in a pLKO.1-puro vector $(6 \mu \mathrm{g})$ (Sigma-Aldrich; Merck KGaA). Lentiviruses were harvested at $48 \mathrm{~h}$ post-transfection. RPMI-8226 cells $\left(1 \times 10^{6}\right.$ cells/well in 6-well plates) were infected with fresh lentiviruses, then Polybrene $(8 \mu \mathrm{g} / \mathrm{ml}$, Sigma-Aldrich; Merck
$\mathrm{KGaA}$ ) was added in the culture medium. All wells were refreshed with $2 \mathrm{ml}$ fresh IMDM medium after $2-4 \mathrm{~h}$ at $37^{\circ} \mathrm{C}$, and the successfully infected cells were selected by using $1.0 \mu \mathrm{g} / \mathrm{ml}$ puromycin.

Statistical analysis. Data collected in all the experiments are expressed as the mean \pm standard error of the mean. Statistical analysis was performed using GraphPad Prism software (version 5.0; GraphPad Software, Inc., La Jolla, CA). A 2-sided Student's t-test was performed to assess the difference between two groups and one-way analysis of variance with post hoc intergroup comparisons using Tukey's test was used to perform comparisons between multiple groups. $\mathrm{P}<0.05$ was considered to indicate a statistically significant difference. Each experiment was performed at least three times independently.

\section{Results}

PP abrogates the Wnt/ $\beta$-catenin pathway in human MM cells. In the present study, the molecular events resulting from the effects of PP (Fig. 1A) triggering on the Wnt/ $\beta$-catenin pathway were characterized. The results revealed that the total level of $\beta$-catenin and the level of phosphorylated $\beta$-catenin decreased as the dose of PP increased in MM cells (Fig. 1B). Although phosphorylated $\beta$-catenin facilitates the proteasomal degradation of total $\beta$-catenin, the decrease in phosphorylated $\beta$-catenin may be due to a lack of total $\beta$-catenin, mediated by PP. The phosphorylation status of glycogen synthase kinase $3 \beta$ (GSK $3 \beta)$ in MM cells was measured following PP treatment, since $\beta$-catenin is regulated by GSK $3 \beta$ in the $W n t / \beta$-catenin signaling pathway. PP downregulated S9-phosphorylated GSK3 $\beta$ (inactive GSK3 $\beta$ ), whereas levels of Y216-phosphorylated GSK3 $\beta$ (active GSK3 $\beta$ ) exhibited no change (Fig. 1B).

$\beta$-catenin serves a notable function in PP-induced apoptosis. To examine the function of $\beta$-catenin in PP-mediated apoptosis, RPMI-8226 cells transfected with empty vector or 
A<smiles>Cc1cc(/C=C/c2ccc3cc(N(C)C)ccc3[n+]2C)c(C)n1-c1ccccc1</smiles>

Pyrvinium Pamoate

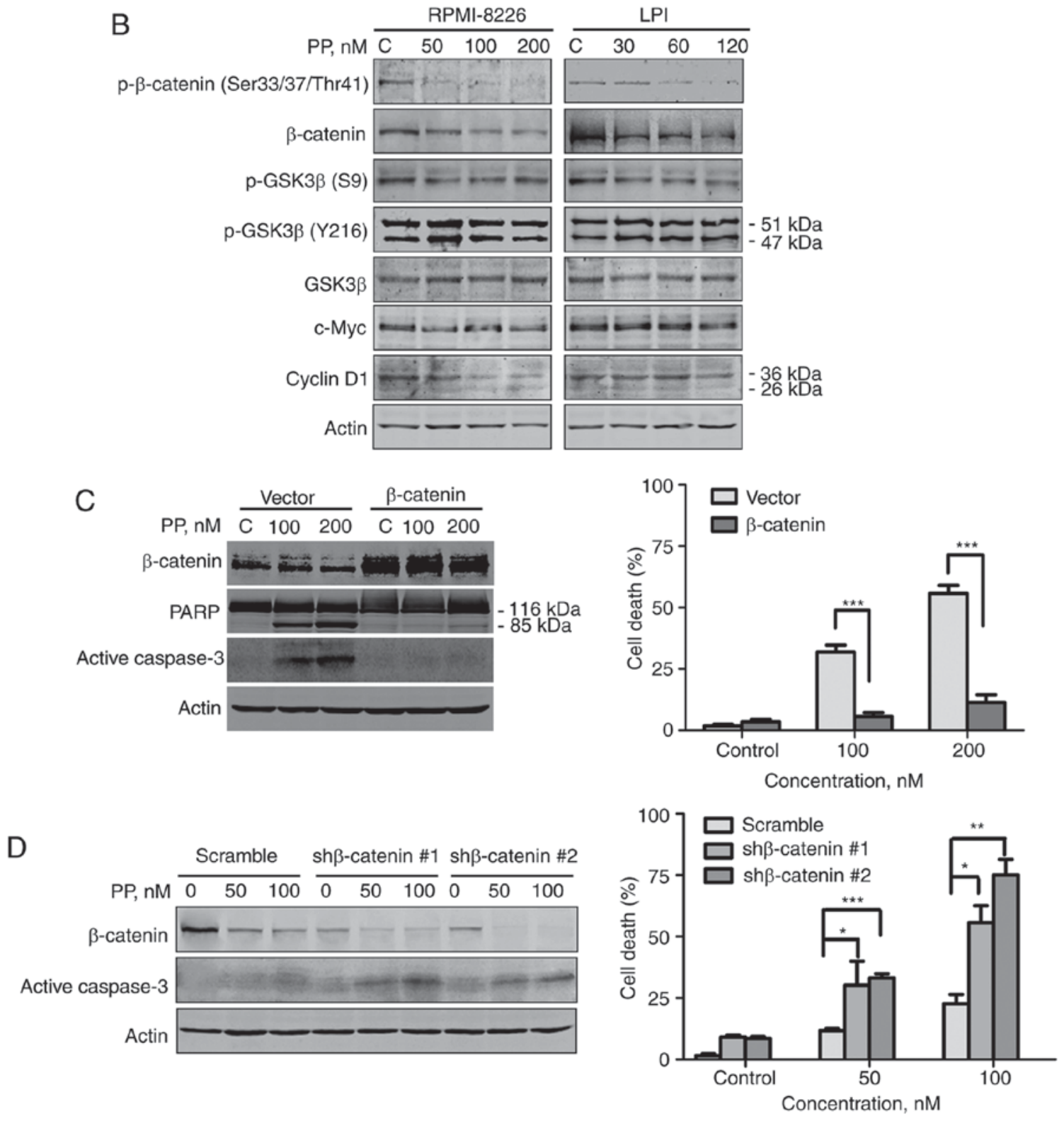

Figure 1. PP blocks Wnt/ $\beta$-catenin signaling. (A) Molecular structure of PP. (B) RPMI-8226 and LP1 cells were treated with PP at the indicated concentrations for $48 \mathrm{~h}$, and western blot analysis was performed with whole-cell lysates. RPMI- 8226 cells were transfected with (C) plasmids (empty vector or $\beta$-catenin) or (D) shRNAs (scramble or $\beta$-catenin-targeting). The cells were treated with the indicated concentration of PP, cell lysates were subjected to western blot analysis and the degree of cell death was determined using a trypan blue exclusion assay. ${ }^{*} \mathrm{P}<0.05,{ }^{* *} \mathrm{P}<0.01,{ }^{* * * *} \mathrm{P}<0.001 ; \beta$-catenin vs. empty vector , sh $\beta$-catenin $\# 1$ or sh $\beta$-catenin \#2 vs. Scramble, respectively. shRNA, short hairpin RNA; PP, pyrvinium pamoate; p-GSK3 $\beta$, phosphorylated glycogen synthase kinase $3 \beta$; PARP, poly (ADP-ribose) polymerase.

a $\beta$-catenin-encoding plasmid were treated with control culture medium or PP for $48 \mathrm{~h}$. The cells transfected with the $\beta$-catenin-encoding plasmid underwent no increase in apoptosis, whereas empty vector-transfected cells exhibited extensive apoptosis, which was indicated by the specific cleavage of PARP, activation of caspase-3 and trypan blue 

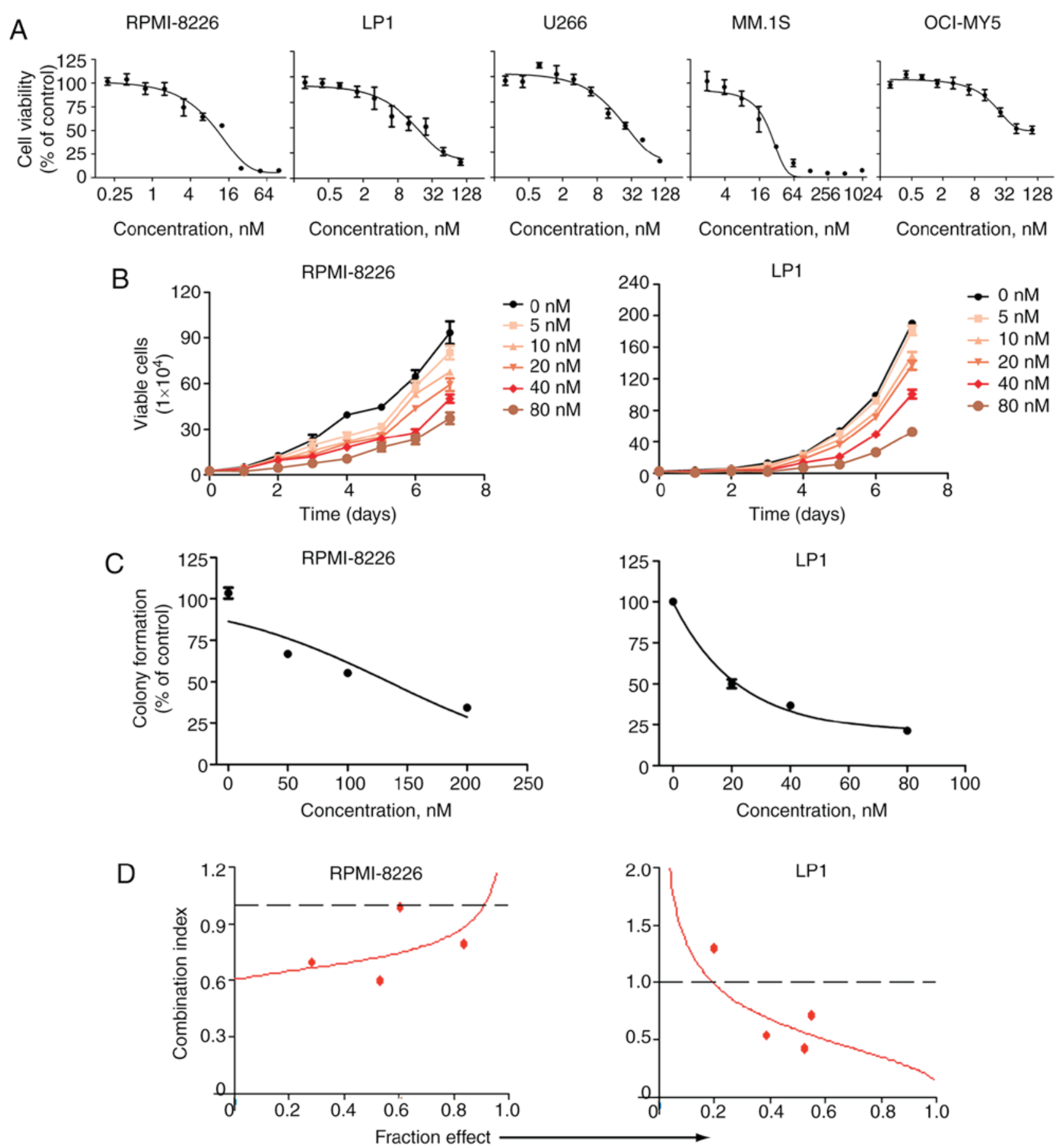

Figure 2. PP suppresses the growth of MM cells. (A) MM RPMI-8226, LP1, U266, MM.1S, and OCI-MY5 cells were exposed to the indicated concentrations of PP for $72 \mathrm{~h}$. Cell viability was determined by MTS assay. (B) Inhibition of the viability of RPMI-8226 and LP1 by PP in vitro (cells were counted using the trypan blue exclusion assay) over 7 days in culture. (C) PP inhibited the clonogenicity of MM cells. RPMI-8226 and LP1 cells were treated with PP for 48 h, and then cells were washed and seeded in soft agar for 2 weeks, following which the colonies were counted. (D) The synergistic effect of the combination of PP and bortezomib in MM cells RPMI-8226 and LP1was observed. PP, pyrvinium pamoate; MM, multiple myeloma.

exclusion assay (Fig. 1C). Conversely, knockdown of $\beta$-catenin with the specific $\beta$-catenin-shRNA greatly increased the capability of PP to induce apoptosis (Fig. 1D, $\mathrm{P}<0.05$ for all comparisons). $\beta$-Catenin, may therefore serve a notable function in apoptosis mediated by PP.

PP suppresses the growth of MM cells. The effect of PP on the viability of MM cells was evaluated. U266, RPMI-8226, MM.1S, OCI-MY5 and LP1 cells were incubated with or without $(100,50,25,12.5,6.25,3.12,1.56,0.78,0.39$ and
$0.19 \mathrm{nM}$ ) of PP for $72 \mathrm{~h}$, and the viability of these cells was examined using MTS assay. PP inhibited the growth of all cells in a dose-dependent manner. The half-maximal inhibitory concentrations $\left(\mathrm{IC}_{50}\right)$ for U266, RPMI-8226, MM.1S, OCI-MY5 and LP1 cells were 19.6, 27.1, 48.4, 31.1 and $82.1 \mathrm{nM}$, respectively (Fig. 2A). The anti-proliferative effects of PP were assessed over a number of days in RPMI-8226 and LP1 cells. PP demonstrated potent anti-proliferative effects for RPMI-8226 and LP1 cells (Fig. 2B). The effect of $\mathrm{PP}$ on anchorage-independent growth was measured using 
A

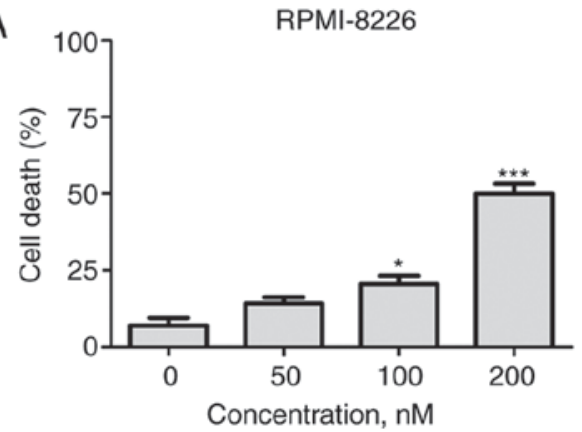

B

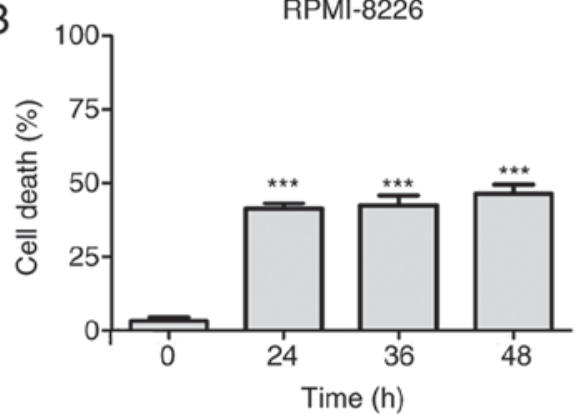

C

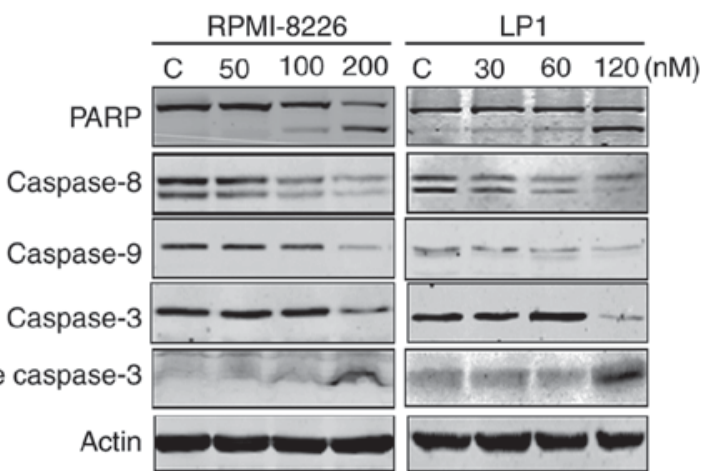

D

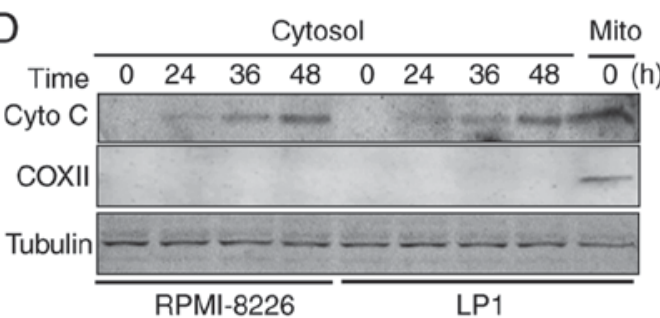

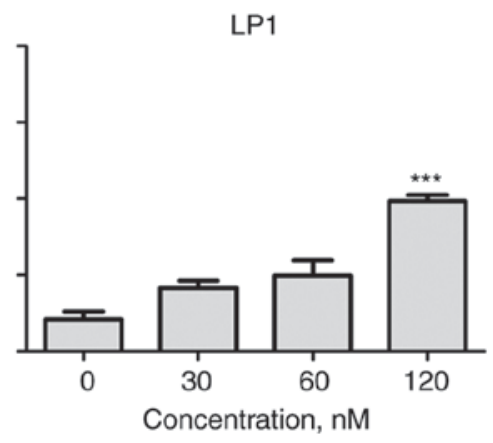

LP1
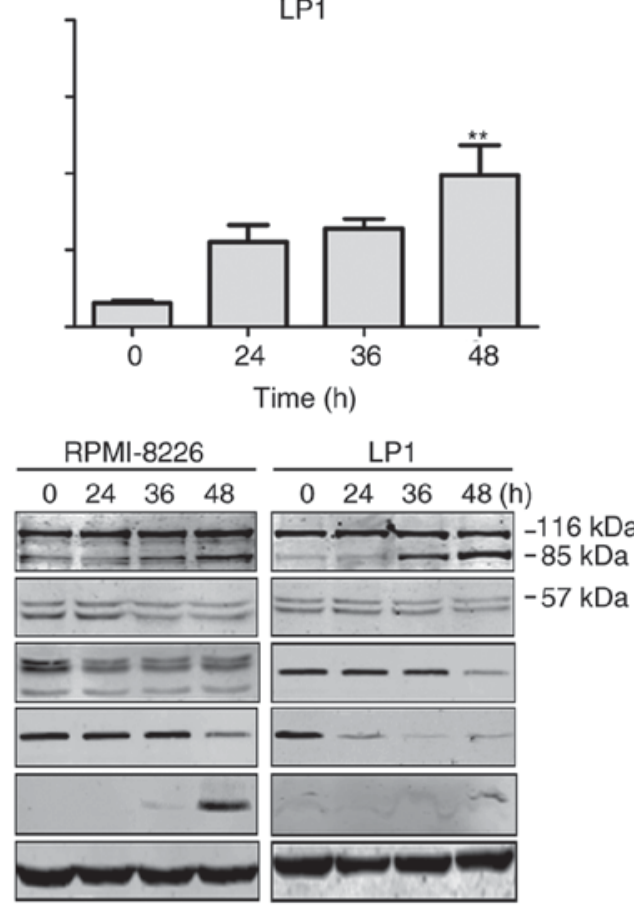

E

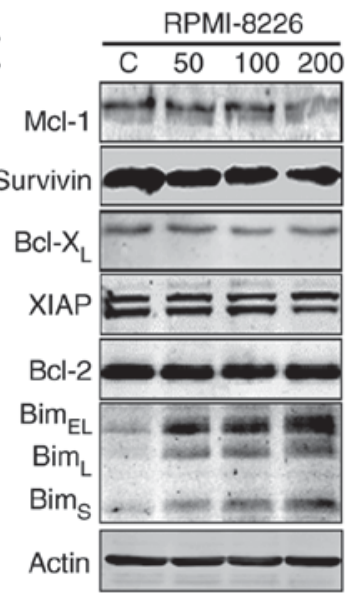

\begin{tabular}{llll}
\multicolumn{4}{c}{ LP1 } \\
\hline C & 30 & 60 & 120 \\
(nM)
\end{tabular}

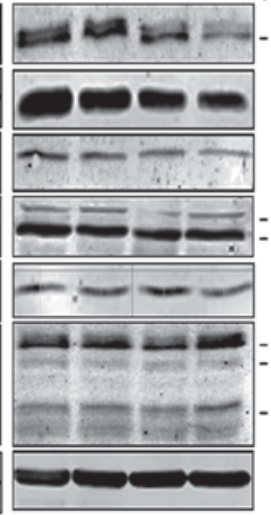
-42 kDa

$64 \mathrm{kDa}$ $57 \mathrm{kDa}$

$23 \mathrm{kDa}$

$16 \mathrm{kDa}$

13 kDa

Figure 3. PP induces apoptosis in MM. (RPMI-8226 and LP1 cells were treated with PP at (A) escalating concentrations for 48 h or (B) a fixed concentration (200 nM for RPMI-8226 and $120 \mathrm{nM}$ for LP1) for different durations. A trypan blue exclusion assay was performed to count viable cells. (C) Western blotting analysis of RPMI-8226 and LP1 cells treated with PP for $48 \mathrm{~h}$ or at a fixed concentration (200 nM for RPMI-8226 and $120 \mathrm{nM}$ for LP1) for different durations. (D) RPMI-8226 and LP-1 cells were exposed to the indicated levels of PP for $48 \mathrm{~h}$; the levels of cytochrome $c$ in the cytosolic fractions were monitored by western blotting. COXII served as a mitochondrial indicator to exclude the contamination of cytosolic fraction by mitochondria. (E) Western blotting analysis of apoptosis-associated proteins in RPMI-8226 and LP1 cells upon treatment with $\mathrm{PP}$. ${ }^{*} \mathrm{P}<0.05,{ }^{* *} \mathrm{P}<0.01,{ }^{* * *} \mathrm{P}<0.001 ;$ compared with the control. PP, pyrvinium pamoate; MM, multiple myeloma; Bcl-2, B-cell lymphoma 2; COXII, cyclooxygenase 2; Bcl-xL, Bcl-2-assocaited X; BclXL, Bcl-extra large; Bim, Bcl2-like protein; XIAP, X-linked inhibitor of apoptosis protein; Mcl-1, induced myeloid leukemia cell differentiation protein.

RPMI-8226 and LP1 cells in soft agar culture via a colony formation assay. PP inhibited the number of surviving clonogenic $\mathrm{MM}$ cells in a dose-dependent fashion, with $\mathrm{IC}_{50}$ values of $\sim 134$ and $37 \mathrm{nM}$, respectively (Fig. 2C). 


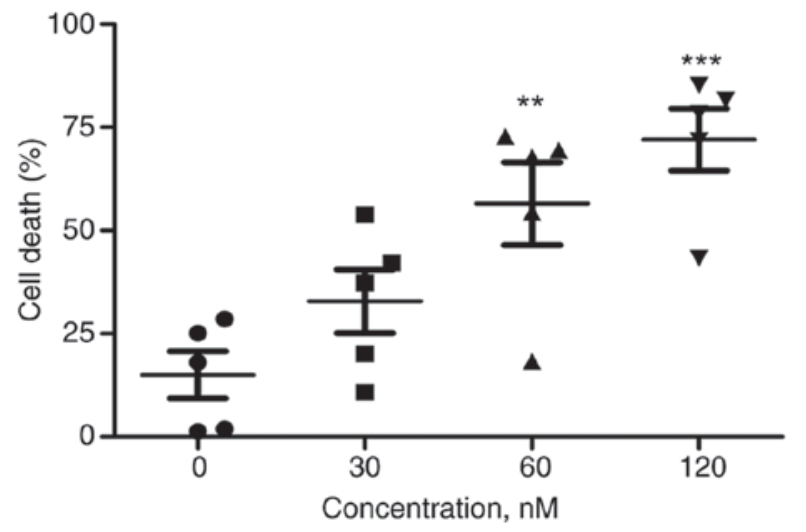

Figure 4. PP is effective in MM primary cells. The primary cells from patients with MM $(n=5)$ were treated with $P P$ at escalating concentrations for $48 \mathrm{~h}$ and subjected to the trypan blue assay. ${ }^{* *} \mathrm{P}<0.01,{ }^{* * *} \mathrm{P}<0.001$; compared with the control. PP, pyrvinium pamoate; MM, multiple myeloma.

Bortezomib, one of the ubiquitin-proteasome pathway inhibitors, is the primary frontline drug for patients with MM. A combined effect was observed between PP and bortezomib with serial fixed ratio dilutions respectively at in MM cells (20,000 per well, $37^{\circ} \mathrm{C}$ ). MTS assay was performed by incubating MM cells in a serially diluted mixture of PP and bortezomib at a fixed ratio for $72 \mathrm{~h}$, which revealed synergism between PP and bortezomib based on the combination index (Fig. 2D) (23).

PP induces apoptosis in MM cells. To investigate whether PP was able to trigger intrinsic apoptosis in MM cells, it was evaluated using a trypan blue exclusion assay. PP markedly induced cell death in RPMI-8226 and LP1 cells in a dose- and time-dependent manner (Fig. 3A and B). Western blotting analysis revealed that PP promoted specific cleavage of PARP, caspase-8, -9 and -3 in RPMI-8226 and LP1 cells in a dose- and time-dependent manner (Fig. 3C), further confirming the occurrence of apoptosis. Cyto $c$ levels in the cytosolic fraction were increased in a time-dependent manner following exposure of RPMI-8226 and LP1 cells to PP (Fig. 3D). These results indicate that PP is able to induce intrinsic apoptosis in MM cells.

Effect of PP on the expression of apoptosis-associated proteins. To investigate the mechanism of PP-induced apoptosis, the expression of apoptosis-associated proteins was assessed. The levels of Mcl-1 and survivin were decreased, $\operatorname{Bim}\left(\mathrm{Bim}_{\mathrm{EL}}, \mathrm{Bim}_{\mathrm{L}}\right.$ and $\mathrm{Bim}_{\mathrm{S}}$ isoforms) was increased in a dose-dependent fashion and the levels of XIAP, Bcl-XL and Bcl-2 exhibited no alteration (Fig. 3E).

PP induces an evident increase in cell death in MM primary cells. Primary cells from 5 patients with MM were exposed to escalating concentrations of PP for $48 \mathrm{~h}$, and the incidence of cell death was determined by the trypan blue exclusion assay. As indicated in Fig. 4, PP was effective in inducing cell death in primary MM cells.

\section{Discussion}

The results of the present study demonstrated that PP potently attenuated growth and induced apoptosis in MM cell lines and primary tumor cells; the induction of apoptosis by PP may be a result of its inhibitory effect on the Wnt/ $\beta$-catenin pathway. Furthermore, PP exhibits a synergism with bortezomib, a frontline drug for patients with MM, in killing MM cells. Thus, PP may exhibit potential therapeutic applications with bortezomib as an adjuvant drug in clinical MM treatment.

Due to cost- and time-saving benefits, identifying novel applications for established drugs attracts more attention than the identification of novel drugs. As a quinolone-derived cyanine dye, PP has been safely used as an anthelmintic since the 1950s. In the present study, PP demonstrated antineoplastic activity in MM cells. Pharmacokinetic studies have identified that tablets or suspensions of PP, administered as a single $350 \mathrm{mg} /$ day dose to healthy volunteers, are much higher than the concentrations at which it reaches antitumor activity (26). PP delivered orally was not genotoxic in the mouse colon, even at doses $\leq 12.5$ times the recommended human dosage (27). PP exhibits a number of difficulties in solubility and absorption across the gastrointestinal tract; however, other soluble pyrvinium salts and structural mimetics may exhibit therapeutic promise $(28,29)$.

The Wnt/ $\beta$-catenin pathway serves an important function in embryonic development, the self-renewal and maintenance of stem cells, and as a hallmark of carcinogenesis $(30,31)$. In $\mathrm{MM}$, canonical Wnt/ $\beta$-catenin signaling is aberrant, which associates with MM cell growth, survival and migration. As a participant in the canonical Wnt signaling pathway, $\beta$-catenin is degraded by ubiquitination through GSK $3 \beta$ and its kinase activity is inhibited by S9 phosphorylation. Inhibiting the Wnt/ $\beta$-catenin pathway will cause a cascade of events; $\beta$-catenin levels decrease, as will the expression of downstream target genes, including axin 2, MYC and cyclin D1. A study has demonstrated that $\beta$-catenin silencing induces autophagy and apoptosis in MM cells by increasing the levels of pro-apoptotic protein Bax and active caspase-3, and decreasing the expression of anti-apoptotic protein Bcl-2 (6). Furthermore, a previous study has identified that blocking the Wnt/ $\beta$-catenin pathway may eliminate stem-like myeloma cells (32). These studies identified the therapeutic efficacy of blocking Wnt/ $\beta$-catenin in MM. Consistent with the previous studies, PP has an inhibitory effect on the expression of Wnt $/ \beta$-catenin, which mediates cell death in $\mathrm{MM}$ cells. The present results revealed a decrease in the total level of Wnt/ $\beta$-catenin and the abrogation of its phosphorylation in PP-treated MM cells. The reduction in phosphorylation of its downstream target GSK3 $\beta$ at S9 was also observed.

Taken together, the results of the present study indicate PP potently kills MM cells and primary cells taken from patients with MM by blocking Wnt/ $\beta$-catenin expression, and there is a synergism between bortezomib and PP in killing tumor cells. Considering that PP is already an FDA-approved anthelmintic drug, a clinical trial of PP for patients with MM may be warranted.

\section{Acknowledgements}

The present study was supported by National Natural Science Funds (grant nos. U1301226, 81373434, 81025021, and 91213304), the Research Foundation of Education Bureau 
of Guangdong Province, China (grant no. cxzd1103), the Research Foundation of Guangzhou Bureau of Science and Technology, and Natural Science Foundation of Guangdong Province (grant no. 2015A030312014).

\section{Competing interests}

The authors declare that they have no competing interests.

\section{References}

1. Kyle RA and Rajkumar SV: Multiple myeloma. Blood 111: 2962-2972, 2008.

2. Yarde DN, Oliveira V, Mathews L, Wang X, Villagra A, Boulware D, Shain KH, Hazlehurst LA, Alsina M, Chen DT, et al Targeting the Fanconi anemia/BRCA pathway circumvents drug resistance in multiple myeloma. Cancer Res 69: 9367-9375, 2009.

3. Gao M, Kong Y, Yang G, Gao L and Shi J: Multiple myeloma cancer stem cells. Oncotarget 7: 35466-35477, 2016.

4. Kikuchi J, Koyama D, Wada T, Izumi T, Hofgaard PO, Bogen B and Furukawa Y: Phosphorylation-mediated EZH2 inactivation promotes drug resistance in multiple myeloma. J Clin Invest 125: 4375-4390, 2015.

5. Meads MB, Fang B, Mathews L, Gemmer J, Nong L, Rosado-Lopez I, Nguyen T, Ring JE, Matsui W, MacLeod AR, et al: Targeting PYK2 mediates microenvironment-specific cell death in multiple myeloma. Oncogene 35: 2723-2734, 2016.

6. Su N, Wang P and Li Y: Role of Wnt/b-catenin pathway in inducing autophagy and apoptosis in multiple myeloma cells. Oncol Lett 12: 4623-4629, 2016.

7. Abe M, Harada T and Matsumoto T: Concise review: Defining and targeting myeloma stem cell-like cells. Stem Cells 32: 1067-1073, 2014.

8. Munshi NC and Anderson KC: New strategies in the treatment of multiple myeloma. Clin Cancer Res 19: 3337-3344, 2013.

9. Yang Y, Shi J, Tolomelli G, Xu H, Xia J, Wang H, Zhou W, Zhou Y, Das S, Gu Z, et al: RAR $\alpha 2$ expression confers myeloma stem cell features. Blood 122: 1437-1447, 2013.

10. Qiang YW, Endo Y, Rubin JS and Rudikoff S: Wnt signaling in B-cell neoplasia. Oncogene 22: 1536-1545, 2003.

11. Sukhdeo K, Mani M, Zhang Y, Dutta J, Yasui H, Rooney MD, Carrasco DE, Zheng M, He H, Tai YT, et al: Targeting the beta-catenin/TCF transcriptional complex in the treatment of multiple myeloma. Proc Natl Acad Sci USA 104: 7516-7521, 2007.

12. Derksen PW, Tjin E, Meijer HP, Klok MD, MacGillavry HD, van Oers $\mathrm{MH}$, Lokhorst HM, Bloem AC, Clevers $\mathrm{H}$, Nusse R, et al: Illegitimate WNT signaling promotes proliferation of multiple myeloma cells. Proc Natl Acad Sci USA 101: 6122-6127, 2004.

13. Chapman MA, Lawrence MS, Keats JJ, Cibulskis K, Sougnez C, Schinzel AC, Harview CL, Brunet JP, Ahmann GJ, Adli M, et al: Initial genome sequencing and analysis of multiple myeloma. Nature 471: 467-472, 2011.

14. Beck JW, Saavedra D, Antell GJ and Tejeiro B: The treatment of pinworm infections in humans (enterobiasis) with pyrvinium chloride and pyrvinium pamoate. Am J Trop Med Hyg 8: 349-352, 1959.

15. Esumi H, Lu J, Kurashima Y and Hanaoka T: Antitumor activity of pyrvinium pamoate, 6-(dimethylamino)-2-[2-(2,5-dimethyl1-phenyl-1H-pyrrol-3-yl)ethenyl]-1-methyl-quinolinium pamoate salt, showing preferential cytotoxicity during glucose starvation. Cancer Sci 95: 685-690, 2004.
16. Thorne CA, Hanson AJ, Schneider J, Tahinci E, Orton D, Cselenyi CS, Jernigan KK, Meyers KC, Hang BI, Waterson AG, et al: Small-molecule inhibition of Wnt signaling through activation of casein kinase $1 \alpha$. Nat Chem Biol 6: 829-836, 2010.

17. Tomitsuka E, Kita K and Esumi H: The NADH-fumarate reductase system, a novel mitochondrial energy metabolism, is a new target for anticancer therapy in tumor microenvironments. Ann N Y Acad Sci 1201: 44-49, 2010

18. Jones JO, Bolton EC, Huang Y, Feau C, Guy RK, Yamamoto KR, Hann B and Diamond MI: Non-competitive androgen receptor inhibition in vitro and in vivo. Proc Natl Acad Sci USA 106: 7233-7238, 2009.

19. Zhang Z, Tong J, Tang X, Juan J, Cao B, Hurren R, Chen G, Taylor P, Xu X, Shi CX, et al: The ubiquitin ligase HERC4 mediates c-Maf ubiquitination and delays the growth of multiple myeloma xenografts in nude mice. Blood 127: 1676-1686, 2016.

20. Jin B, Ding K and Pan J: Ponatinib induces apoptosis in imatinib-resistant human mast cells by dephosphorylating mutant D816V KIT and silencing b-catenin signaling. Mol Cancer Ther 13: 1217-1230, 2014.

21. Jin B, Wang C, Li J, Du X, Ding K and Pan J: Anthelmintic niclosamide disrupts the interplay of p65 and FOXM1/ $\beta$-catenin and eradicates leukemia stem cells in chronic myelogenous leukemia. Clin Cancer Res 23: 789-803, 2017

22. Jin Y, Cao Q, Chen C, Du X, Jin B and Pan J: Tenovin-6-mediated inhibition of SIRT1/2 induces apoptosis in acute lymphoblastic leukemia (ALL) cells and eliminates ALL stem/progenitor cells. BMC Cancer 15: 226, 2015.

23. Jin Y, Ding K, Wang D, Shen M and Pan J: Novel thiazole amine class tyrosine kinase inhibitors induce apoptosis in human mast cells expressing D816V KIT mutation. Cancer Lett 353: 115-123, 2014.

24. Jin Y, Zhou J, Xu F, Jin B, Cui L, Wang Y, Du X, Li J, Li P, Ren R and Pan J: Targeting methyltransferase PRMT5 eliminates leukemia stem cells in chronic myelogenous leukemia. J Clin Invest 126: 3961-3980, 2016.

25. Jin Y, Lu Z, Ding K, Li J, Du X, Chen C, Sun X, Wu Y, Zhou J and Pan J: Antineoplastic mechanisms of niclosamide in acute myelogenous leukemia stem cells: Inactivation of the NF-kappaB pathway and generation of reactive oxygen species. Cancer Res 70: 2516-2527, 2010.

26. Smith TC, Kinkel AW, Gryczko CM and Goulet JR: Absorption of pyrvinium pamoate. Clin Pharmacol Ther 19: 802-806, 1976.

27. Goldberg MT: Pyrvinium pamoate lacks in vivo genotoxicity in the colon. Toxicol Appl Pharmacol 74: 293-295, 1984.

28. Ishii I, Harada Y and Kasahara T: Reprofiling a classical anthelmintic, pyrvinium pamoate, as an anti-cancer drug targeting mitochondrial respiration. Front Oncol 2: 137, 2012.

29. Buchanan RA, Barrow WB, Heffelfinger JC, Kinkel AW, Smith TC and Turner JL: Pyrvinium pamoate. Clin Pharmacol Ther 16: 716-719, 1974.

30. Saraswati S, Deskins DL, Holt GE and Young PP: Pyrvinium, a potent small molecule Wnt inhibitor, increases engraftment and inhibits lineage commitment of mesenchymal stem cells (MSCs). Wound Repair Regen 20: 185-193, 2012.

31. Li B, Flaveny CA, Giambelli C, Fei DL, Han L, Hang BI, Bai F, Pei XH, Nose V, Burlingame O, et al: Repurposing the FDA-approved pinworm drug pyrvinium as a novel chemotherapeutic agent for intestinal polyposis. PLoS One 9: e101969, 2014.

32. Zeng D, Liu M and Pan J: Blocking EZH2 methylation transferase activity by GSK126 decreases stem cell-like myeloma cells. Oncotarget 8: 3396-3411, 2017.

33. Nanni C, Versari A, Chauvie S, Bertone E, Bianchi A, Rensi M, Bellò M, Gallamini A, Patriarca F, Gay F et al: Interpretation criteria for FDG PET/CT in multiple myeloma (IMPeTUs): Final results. IMPeTUs (Italian myeloma criteria for PET USe). Eur J Nucl Med Mol Imaging, Dec 21, 2017 (Epub ahead of print). 